Nairobi at all, but will be those surrounding the summit meeting planned for Mexico in October under the auspices of the Brandt Commission. This meeting, which will be attended by President Reagan, is expected to set the tone for negotiations between developed and developing nations for the first half of the 1980 s; as a result, it will provide the setting within which any results from Nairobi will inevitably be judged.

David Dickson

\section{To the gulags}

The last two members of the Moscow "Working Commission to Investigate the Use of Psychiatry for Political Purposes", Irina Grivnina and Feliks Serebrov, were last month tried and convicted on charges of anti-Soviet activity. Ms Grivnina was sentenced to five years' internal exile, Mr Serebrov to four years in a labour camp plus five years internal exile.

The "Working Commission" was established in 1977 as part of the general human rights monitoring movement in the Soviet Union, and its members made determined efforts to visit "patients" confined in psychiatric hospitals because of their political beliefs. The commission produced a samizdat (information bulletin) giving details of its findings, and where possible provided colleagues abroad, on a confidential basis, with case notes of the patients investigated. In most cases these notes showed that by nonSoviet standards there were no grounds for compulsory hospitalization.

For these activities commission members have either been forced to emigrate (like Dr Volshanivich) or arrested and charged with disseminating anti-Soviet slander (Article 190/1), or with anti-Soviet propaganda and agitation (Article 70/1). According to Soviet judicial theory, as reiterated recently by Evgenii Smolentsev, Deputy Chairman of the USSR Supreme Court, "in the practice of Soviet courts, there are not and there cannot be convictions for religious and political beliefs" and hence any claim that there are prisoners of conscience in the Soviet Union is antiSoviet propaganda.

According to TASS, Mr Serebrov pleaded guilty under Article 70/1 and admitted knowing that the documents he helped to prepare would be distributed in the West. TASS further recorded that he had "repented" of these actions, but some Moscow sources deny this "repentance", saying that in such a case a far lighter sentence would be expected.

The British Medical Association has tabled a motion for the September meeting of the World Medical Association in Lisbon, condemning both the use of psychiatric methods for political repression and the suppression of the "Moscow Working Commission".

Vera Rich
UK engineering council

\section{New lambs for old}

A new body to safeguard the quality of British engineers is to be set up by Royal Charter, the government announced last week. The Engineering Council, as the body will be known, is the culmination of eighteen months of heated debate since the Committee of Inquiry into the Engineering Profession, chaired by Sir Monty Finniston, recommended that there should be a new organization to oversee the education and registration of engineers.

The Engineering Council's first parttime, unpaid chairman is Sir Kenneth Corfield, chairman of Standard Telephones and Cables Limited. The Department of Industry, which is putting up $£ 1$ million to get the council started, will appoint 15-24 board members - for which it has already received 300 suggestions - and a permanent secretariat in the autumn. After a three-year transition period, the council will elect its own members and will be expected to be selffinancing mainly from fees charged for registration, its chief business.

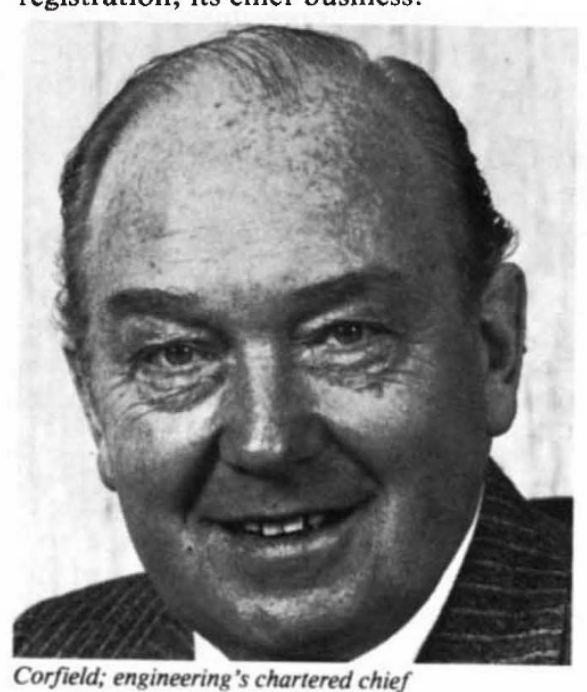

The council is a disappointment to many. Some consider it a poor substitute for the statutory Engineering Authority that Sir Monty's committee had asked for. One issue in the debate has been the relationship between a new body and engineering institutions, especially the Council of Engineering Institutions, which have traditionally chartered engineers and promoted their separate interests through their own Royal Charters. Sir Monty and his supporters fear that the new Royal Charter gives the institutions too much influence. Certainly the new council will not have funds for the improvement of engineering education or even the support of students, as Finniston had asked.

The charter lays down two main roles for the council, each of which it is empowered to delegate in part to the engineering institutions: to determine standards and criteria for the education, training and experience of engineers and to keep a register of those meeting the criteria. Engineers will be eligible to apply for three categories of registration; as professional engineers, technician engineers or engineering technicians. Registration for each category will be in three stages, the first after completing an approved course, the second after training and the third after work experience. Provision is also made for those entering the profession through unorthodox routes. And all those now registered through the Engineers' Registration Board of the Council of Engineering Institutions will automatically be registered with the new council at stage three.

The role of the Engineering Council as registering authority calls into question the future of the Council of Engineering Institutions (CEI). That body, however, expects to carry on with business as usual for perhaps two years until the new council is operating fully. Any change in its status will then mean revoking its own Royal Charter, a move which cannot be taken without a two-thirds majority among its members. The battle for responsibilities could continue much against the wishes of Sir Monty's committee and others who hoped to break the CEI's grip.

Judy Redfearn

\section{University Grants Committee Biting the bullet}

The University Grants Committee considered earlier this year whether it should resign rather than administer the British government's 8.5 per cent cut in support for the universities, according to Dr Edward Parkes, the committee's chairman, in evidence to the House of Commons Select Committee on Education. But, in the end, the committee decided to soldier on, not wishing to be a "fair-weather committee" and believing itself to be the only group with a sufficiently detailed knowledge of the British university system.

Some Members of Parliament were clearly disappointed that the committee had not given them the tangible weapon against the government that a mass resignation would have provided. The select committee was also chagrined that Dr Parkes declined to hand over copies of his correspondence with the Secretary of State for Education, Mr Mark Carlisle, in which - according to his evidence - he had warned the British government of too rapid a contraction of the university system.

Although Dr Parkes's evidence, like that of a delegation from the Committee of Vice-Chancellors and Principals, was taken in private, a transcript of the proceedings was made public last week after the witnesses had confessed themselves puzzled that the hearing had been held in private. Perhaps the select committee had been hoping that its witnesses would have been more open, even gossipy. 